\title{
Analysis of Inbreeding in European Bison
}

\author{
Wanda OLECH
}

Olech W., 1987: Analysis of inbreeding in European bison. Acta theriol., 32, 22: $373-387$ [With 7 Tables \& 4 Figs]

The ancestors of the European bison population currently living in the world consisted of 12 animals only so they are closely related to each other. Inbreeding accompanying such close relationship may form the cause of decrease in vitality and consequent reduction in fertility. The present study analyses the degree of inbreeding in the European bison recorded in the Pedigree Book and determines the effect of such inbreeding on the animals' length of life and reproduction. Investigation was made of total of 3617 European bison of known descent on both the paternal and maternal side. The world population of European bison proved to be highly inbred; the mean inbreeding coefficient is $F=0.210$. The high degree of inbreeding affects the length of animals life. The coefficient of correlation between inbreeding and life span, expressed in days, is significant $(r=-0.12 \pm 0.002)$, that is, the higher the inbreeding coefficient, the shorter the length of animals life. A significant correlation was also found between the inbreeding level and the percentage of deaths of young animals. Inbreeding prolongs the mean period between calvings in cows. It was not found to exert any effect on the age of first calving and the number of calves produced by a cow, and this last conclusion could form part of the success achieved by the rapid restitution of this species.

[Department of Applied Animal Genetics, Institute of the Biological Basis of Animal Breeding, Warsaw Agricultural University, Przejazd 4 05-840 Brwinow, Poland]

\section{INTRODUCTION}

During the International Nature Conservation Congress held in Paris in 1923 a resolution was made to protect and restitute the European bison Bison bonasus (Linnaeus, 1758). At that time there existed only 12 genotypes in population of European bison (Slatis, 1960), and these animals became the ancestors of several thousand European bison later registered in the European Bison Pedigree Book. As the population was so small it was impossible to avoid mating related animals, involving consequent inbreeding in their progeny. The good results obtained in the restitution of European bison show that this species is endowed with both vitality and fertility, and in addition adapts well to natural environment.

Slatis (1960) analyzed inbreeding in European bison and found that it contributes to increase in the percentage of deaths of calves and young 
bison. Increase in inbreeding is usually accompanied by occurrence of inbreeding depression, which is visible when the mean value of the inbreeding coefficient in the population exceeds 10\% (Radomska, 1982). In the case of domestic cattle such increase causes decline of $3.2 \%$ in the milk yield of cows (Robertson, 1954). Hodges (1979) found decrease in annual milk production of $22.8 \mathrm{~kg}$ per $1 \%$ increase in inbreeding in a herd of Holstein-Friesian cattle. Inbreeding in meat-producing breeds of cattle has an unfavourable effect on the fertility of cows, and on vitality and body weight of calves (Dinkel, 1972; Keller \& Brinks, 1978). The effect of inbreeding on length of intervals between successive calvings was found in cattle by Hodges (1978).

The present knowledge of relationship between European bison is incomplete, as it is based on the study by Slatis (1960), and therefore does not include animals living in recent years. The purpose of the present paper is to investigate the level of inbreeding in European bison population and to extend and supplement the studies initiated by Slatis.

Analysis of the degree of inbreeding in European bison registered in the Pedigree Book and assessment of the effect of inbreeding on length of life and on reproduction will provide better knowledge of the "congenital resistance" of this species to inbreeding depression, and may also prove useful in further breeding work.

\section{MATERIAL AND METHODS}

The material consisted of data taken from the European Bison Pedigree Books issued up to 1978 (EBPB, 1946-1978). It was next supplemented by material relating to 1979 , available in the editorial office of Pedigree Book. Animals of unknown origin have been omitted from the analysis.

The inbreeding coefficient was calculated for each bison according with Wright's equation (1922):

$$
\left.F_{x}=1 / 2 \cdot \underset{i=1}{\sum[(1 / 2)} \mathrm{n}_{1}+\mathrm{n}_{2}\left(1+\mathrm{F}_{\mathrm{i}}\right)\right]
$$

where:

$F_{x}$ - inbreeding coefficient of individual $x$,

$k$ - number of common ancestors in the pedigrees of individual $x$ 's parents,

$n_{1}$ - number of generations separating individual $x$ 's mother from common ancestor,

$n_{2}$ - number of generations separating individual $x$ 's mother from common ancestor,

$F_{\mathrm{i}}$ - value of inbreeding coefficient of the common ancestor of individual $x$ 's parents.

Pedigrees were examined up to five generations back, since further analysis has no significant influence on the accuracy of estimating the inbreeding coef- 
ficient. All calculations were made by a computer using the author's own program (available in the Institute of the Biological Basis of Animal Breeding). Individual values of the inbreeding coefficients were kept in working tables while their mean values in groups depending in the division made have been set out in the tables enclosed.

The life length of each animal was calculated on the basis of data on the day of its birth and death. Causes of the animals' deaths have not been taken into consideration in this paper, treating them all as fortuitous. In this way only the natural selection is presumed as eliminating animals unfit to live. The culling of weak specimens by breeders is one of the manifestations of such selection. The date of first calving was established for each cow which produced at least one calf, while for cows with two or more calves calculation was additionally made of the mean length of the interval between calvings.

The number of calves produced by a female during its lifetime was also considered. The following criteria for division of animals were used in this analysis: year of birth, place of birth, month of birth and value of inbreeding coefficient

Taking into account the year of birth, examination was made of the mean values of the characters apart from length of life, and setting them out of diagrams. The effect of the year of birth on length of life was not analyzed, as mean values had been erroneously undervalued for recent years. A similar error, but far less important, relates to the mean number of calves from one mother, but these data have been set out.

In the second division the European bison were classified according to their place of birth. The following places were distinguished: "Europe" apart from Poland and the Soviet Union, the Soviet Union, USA and Canada, and Poland (Białowieża, Borki, Niepolomice, Pszczyna and Smardzewice Reserves). European bison born in other Polish centres have not been included in the analysis on account of their small numbers. Later transfers of bison between breeding centres have not been considered either.

The whole material, irrespective of year and place of birth, was divided into 12 groups depending on the month of birth.

The last division of material was the establishment of eight groups with different degrees of inbreeding. The used criterion for division was half the standard deviation of the inbreeding coefficients estimated for all the animals examined (Fig. 1). Calculation was made for each group of inbreeding degree of the percentage of deaths during two periods of the bison's life, in accordance with the method used by Slatis (1960): 1. up to one month of life, 2. up to two years of life. The values were estimated of correlation coefficients between inbreeding and the remaining characters, and of inbreeding regression coefficients and the remaining characters (the value of the inbreeding coefficients was an independent character). This made it possible to estimate the extent of the change in dependent characters accompanying increase of $1 \%$ in inbreeding.

\section{RESULTS}

The world population of European bison registered in the Pedigree Book, known descent on both sides, until 1979 consisted of 3617 animals, some of which are still alive. My studies have shown that the European bison population is highly inbred. The mean value of the inbreeding 
coefficient is $F=0.210 \pm 0.002$. Among these 3617 animals there are only 255 which are not inbred at all, while 71 animals have the inbreeding coefficient of at least $50 \%$ (Fig. 1).

During the firs $\forall$ years of restitution of the European bison there was

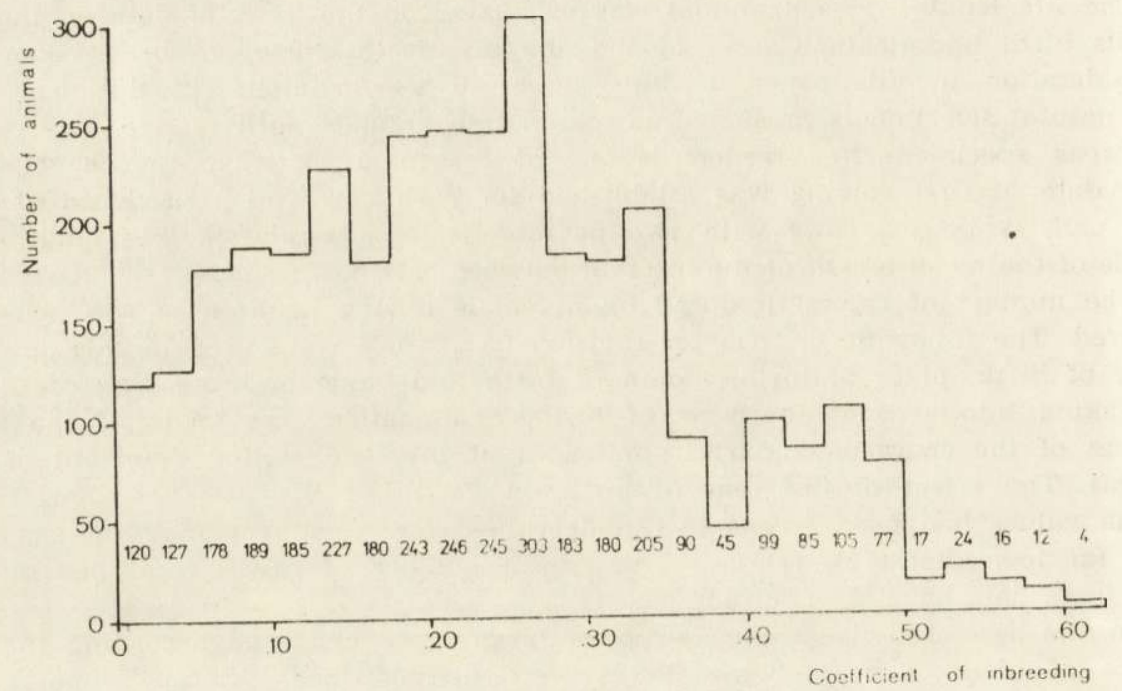

Fig. 1. Distribution of inbreeding coefficients of world population of European bison born up to 1979 inclusive.

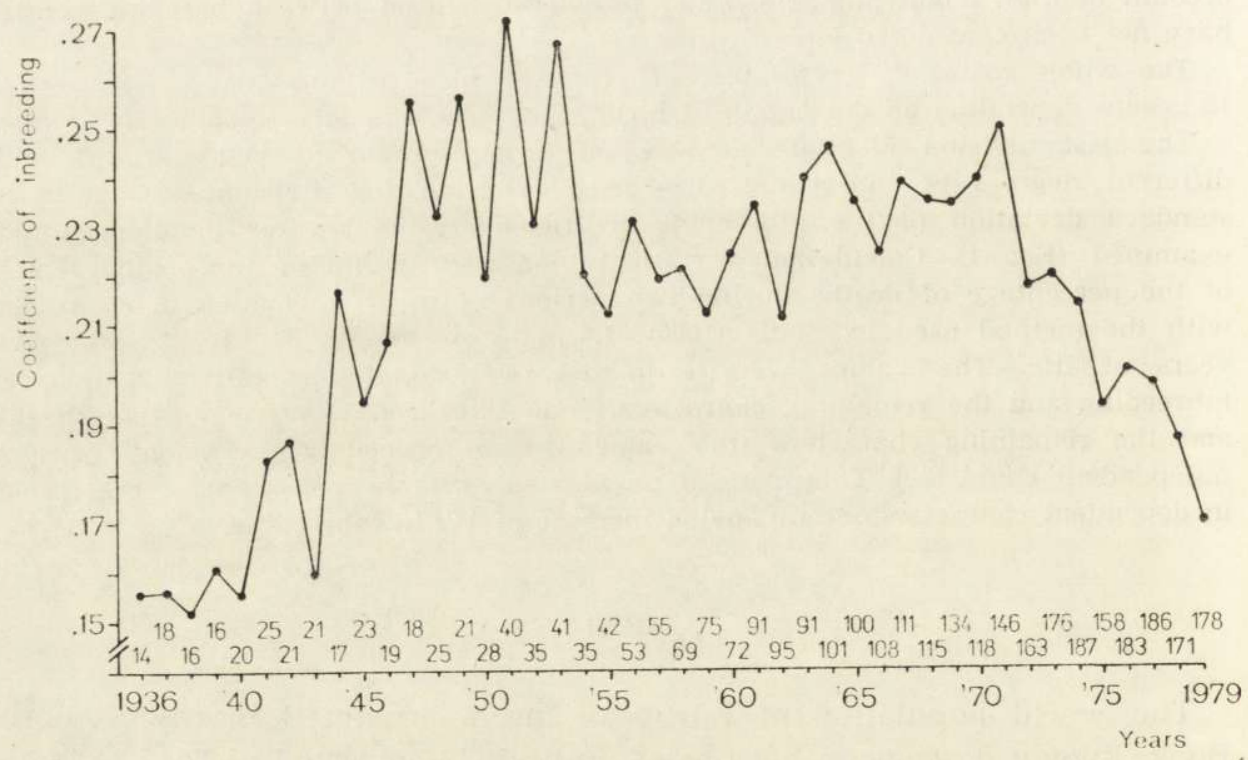

Fig. 2. Mean volue of inbreeding coefficient of European bison depending on year of birth. 
an abrupt increase in the inbreeding coefficient followed by a certain degree of its stabilization (Fig. 2). In recent years, a distinct decrease in the degree of inbreeding of European bison is observed. Changes in the mean value of inbreeding coefficient in the time are highly statistically significant $(p \leqslant 0.01)$.

Table 1

Mean values of inbreeding coefficients for European bison depending on place of birth.

\begin{tabular}{lrrr}
\hline Place of birth & N & $\bar{x}$ & s.e. \\
\hline Europe & 2047 & 0.1783 & 0.0036 \\
USSR & 648 & 0.2430 & 0.0029 \\
USA and Canada & 73 & 0.3435 & 0.0181 \\
Poland: & 285 & 0.2219 & 0.0080 \\
$\quad$ Bialowieża & 50 & 0.2405 & 0.0210 \\
$\quad$ Borki & 159 & 0.1940 & 0.0067 \\
$\quad$ Niepolomice & 234 & 0.3310 & 0.0087 \\
$\quad$ Pszczyna & 23 & 0.1601 & 0.0218 \\
$\quad$ Smardzewice & & & \\
\hline Analysis of variance: & & Mean & $p$ \\
Source of variance & df & squares & \\
& & & \\
\hline Between places of birth & 7 & 1.096 & $<0.01$ \\
Error & 3511 & 0.115 & \\
\hline
\end{tabular}

Table 2

Mean values of inbreeding coefficients for European bison depending on month of birth.

\begin{tabular}{lrrrr}
\hline Month of birth & $\mathrm{N}$ & & $\bar{x}$ & s.e. \\
\hline January & 35 & & 0.2477 & 0.0256 \\
February & 16 & & 0.2605 & 0.0332 \\
March & 22 & & 0.2363 & 0.0260 \\
April & 144 & & 0.1874 & 0.0101 \\
May & 781 & & 0.2019 & 0.0044 \\
June & 527 & & 0.2045 & 0.0048 \\
July & 401 & & 0.2136 & 0.0057 \\
August & 316 & & 0.2130 & 0.0066 \\
September & 224 & 0.2201 & 0.0089 \\
October & 173 & & 0.2299 & 0.0108 \\
Novemebr & 72 & 0.2456 & 0.0171 \\
December & & & \\
Analysis of variance: & & & \\
Source of variance & $\mathrm{df}$ & Mean & $p$ \\
& & squares & \\
\hline Between months of birth & 11 & 0.0415 & $<0.01$ \\
Error & 3590 & 0.0174 & \\
\hline
\end{tabular}


European bison born in USA and Canada are most highly inbreeded $(F=0.34 \pm 0.02)$. Among European bison born in Poland the highest average inbreeding is that in animals born at the Pszczyna reserve $(F=0.33 \pm 0.01)$, and the least in those born at Smardzewice $(F=0.16 \pm$ \pm 0.02 ). Bison born in Europe are less inbred than those born in USA, Poland and the Soviet Union (Table 1).

Examination of degree of inbreeding depending on month of birth of the animals shows that the most inbred individuals are born in winter from December to March (Table 2).

The average number of progeny and average age of cows at their first calving vary depending on the year of birth (Fig. 3). In the first case it is evicent that, omitting the period of World War II, the greatest

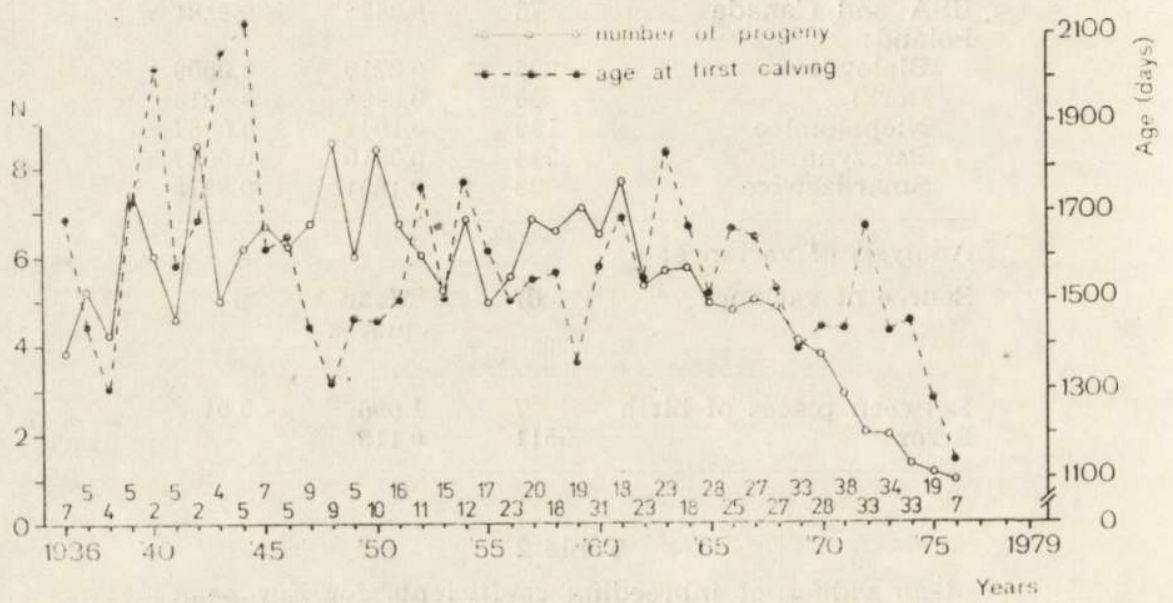

Fig. 3. Mean number of progeny and mean age of first calving of females depending on their year of birth.

number of progeny was found for female bison born during period 1936-1950. From 1963 a decrease in the number of young produced by one mother can be observed. For last few years it may be caused by the lack of data on young cows which has so far produced few calves and thus lowered the mean values.

The average age of first calving has a tendency to decrease in successive years (Fig. 3). This is due to the fact that the period of maturation was shortened, which may be considered as linked with the animals' better living conditions and also inbreeding. The average calving interval for the particular years varies without exhibiting any definite tendency (Fig. 4), except last two years when there are information about few cows only. 
The place of birth of the bison was, however, found to affect the values of the three characters analyzed (Table 3). European bison live longest in Poland, particularly at Niepołomice, whereas the lowest mean life length is characteristic of European bison born in USA and Canada. Females on an average calve latest at Pszczyna and Borki, and earliest at Białowieża, bison from other places exhibiting intermediate values in this respect. Intervals between calvings are longest at Smardzewice and Borki, shortest at Białowieża and the Soviet Union. Bison cows born at Niepołomice have greatest number of calves, and the smallest at Smardzewice and Borki. European bison born in winter live shorter and females born at this time of the year calve earlier and have longer intervals between successive calvings (Table 4). The month of birth of the mother does not affect the number of its progeny.

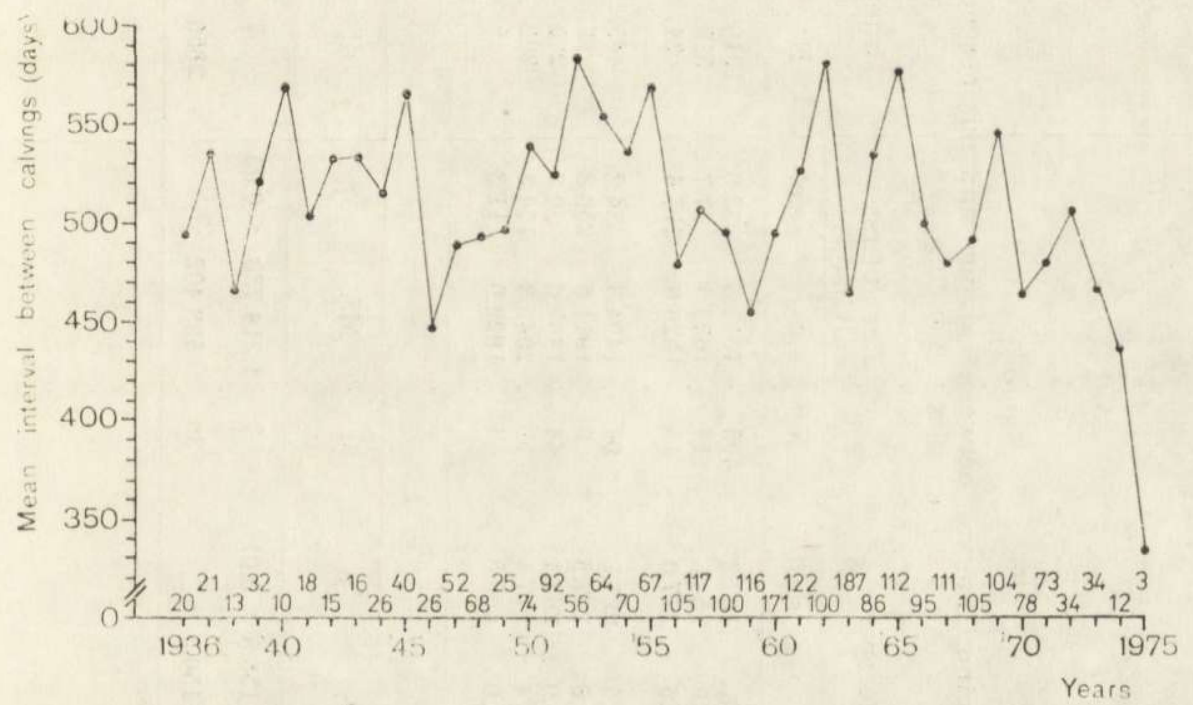

Fig. 4. Mean interval between calvings of females depending on their year of birth.

The relation between inbreeding coefficient of these animals, and their length of life, age of first calving and mean length of the interval between calvings was determined by the coefficients of correlation and linear regression. The length of life of European bison proved to be highly significantly dependent $(p \leqslant 0.01)$ on the value of the inbreeding coefficient $(r=-0.12 \pm 0.002)$. The regression coefficient between these two characters was $b=-19.3$, which means that increase of $1 \%$ in the inbreeding coefficient is accompanied by shortening of the individuals' life by 19.3 days. No connection was, however, found between the age at which the cow first calved and their inbreeding coefficient, but there 


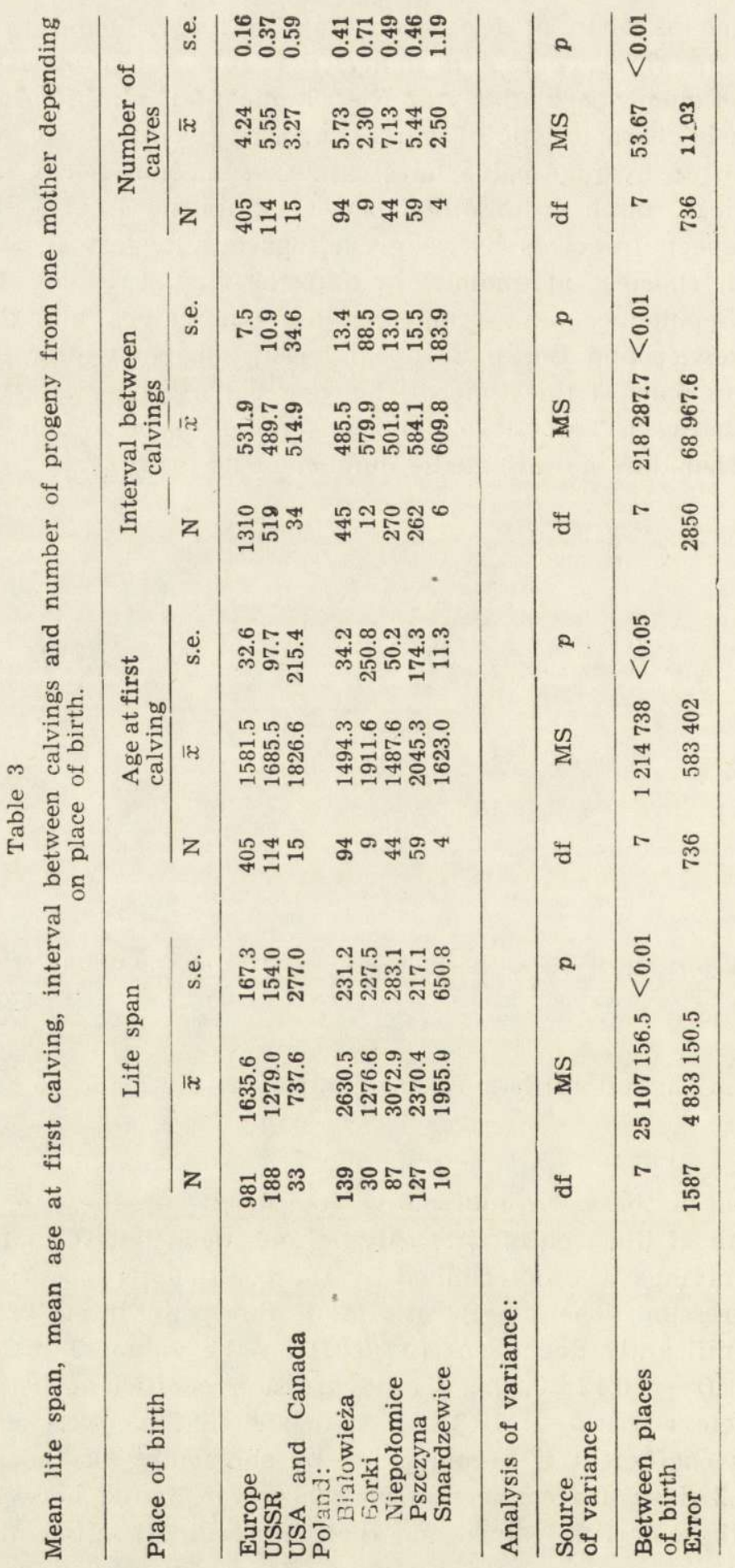




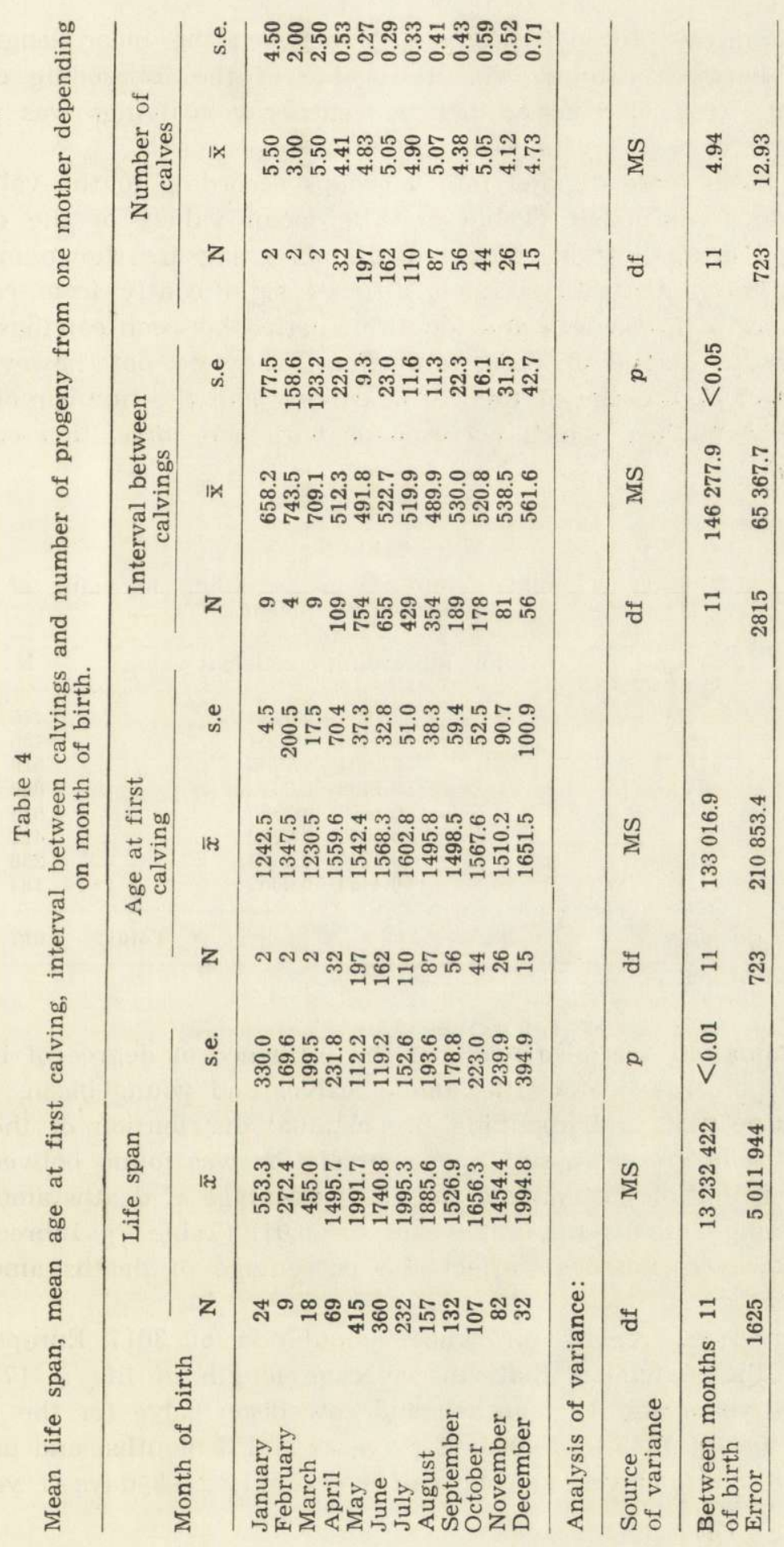


is a significant $(p \leqslant 0.05)$ connection between the mean length of the periocl between calvings and the value of the inbreeding coefficient $(r=0.09 \pm 0.04)$. The period between successive calvings was prolonged by 1.63 days per $1 \%$ of increase in inbreeding.

The bison were divided into 8 groups according to the value of the inbreeding coefficient (Table 5). The mean values of the characters analyzed depending on the group of inbreeding are shown in Table 6 . It was found that the animals differed significantly from each other in respect of life length and length of period between calvings, depending on the degree of their inbreeding. They do not, however, differ in respect of the age of their first calving and the number of progeny from one mother, which corresponds with the correlation coefficients obtained.

Table 5

Division of animals into groups according to value of inbreeding coefficient.

\begin{tabular}{|c|c|c|}
\hline Group & Limit inbreeding coefficient value & $\mathrm{N}$ \\
\hline I & $<\quad 0-0.0433$ & 476 \\
\hline II & $<0.0433-0.1094$ & 486 \\
\hline III & $<0.1094-0.1756$ & 519 \\
\hline IV & $<0.1756-0.2418$ & 658 \\
\hline V & $<0.2418-0.3080$ & 615 \\
\hline VI & $<0.3080-0.3742$ & 421 \\
\hline VII & $<0.3742-0.4404$ & 258 \\
\hline \multirow[t]{2}{*}{ VIII } & $<0.4404-0.6500$ & 184 \\
\hline & Total & 3617 \\
\hline
\end{tabular}

Examination was also made of the influence of degree of inbreeding on the percentage of deaths among calves and young bison. Using the chi-square test, and assuming proportional distribution of the number of deaths in groups, a significant correlation was found between degree of inbreeding of the animals and the percentage of deaths among calves and young animals up to 2 years $(p \leqslant 0.01)$ (Table 7$)$. Inbreeding was not, however, found to affect the percentage of deaths among older animals.

Summarized results for whole population of 3617 European bison justify the statement that: the average length of life is $1772.3 \pm 55.6$ days (4 years and 10 months), and cow bison calve for the first time at the age of $1549.4 \pm 16.9$ days ( 4 years and 3 months) and produce an average of 4.7 calves, i.e. one calf every $511.3 \pm 4.8$ days (1 year and 5 months). 


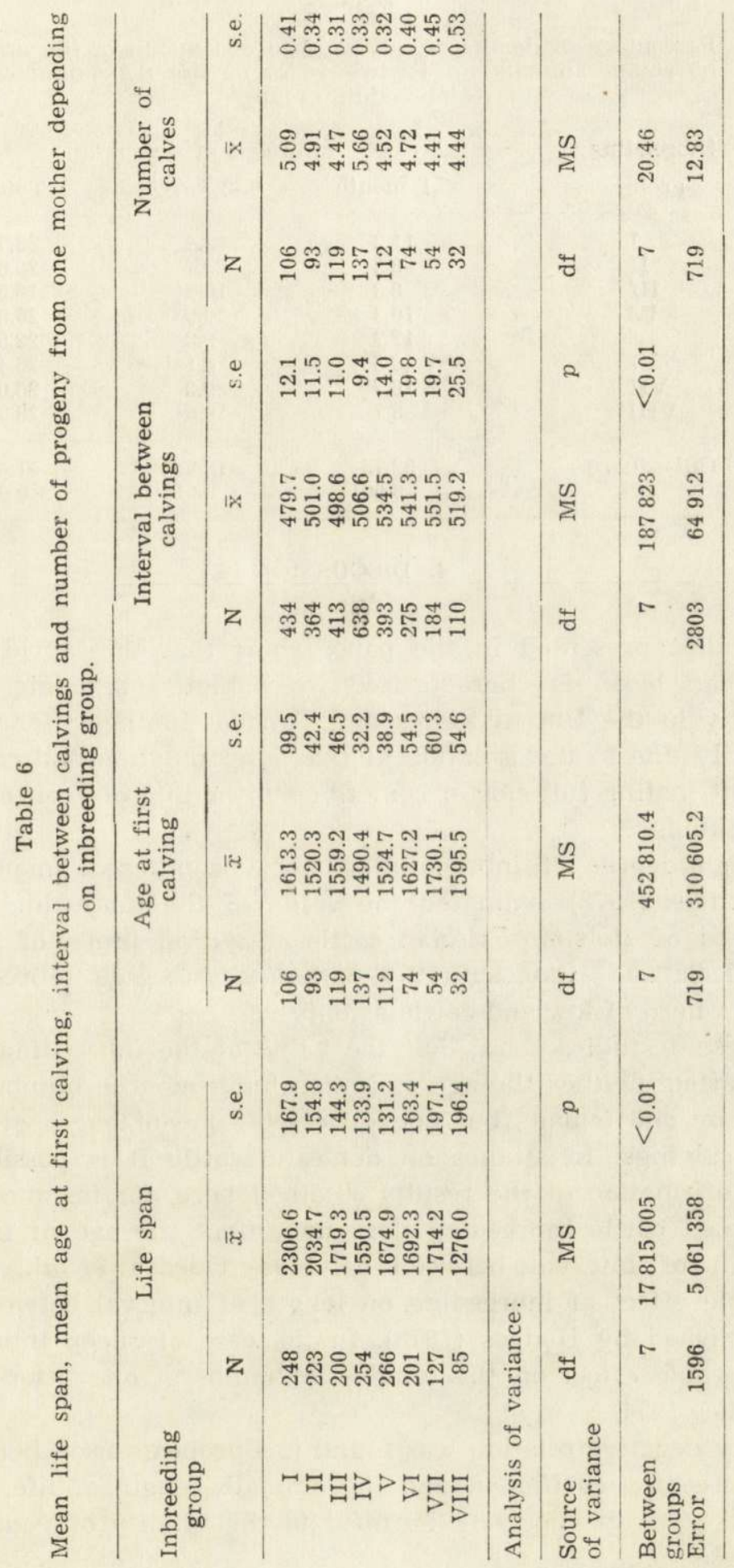


Table 7

\begin{tabular}{|c|c|c|c|}
\hline \multicolumn{4}{|c|}{$\begin{array}{l}\text { Percentage of deaths of calves up to one month of life and } \\
\text { of young animals up to two years of life depending on } \\
\text { inbreeding groups. }\end{array}$} \\
\hline \multirow{2}{*}{$\begin{array}{l}\text { Inbreeding } \\
\text { group }\end{array}$} & \multicolumn{3}{|c|}{ Percent of deaths } \\
\hline & $\leqslant 1$ month & $\leqslant 2$ years & Total \\
\hline I & 11.3 & 12.4 & 23.7 \\
\hline II & 8.9 & 11.7 & 20.6 \\
\hline III & 8.3 & 10.2 & 18.5 \\
\hline IV & 10.3 & 10.5 & 20.8 \\
\hline & 12.7 & 9.8 & 22.5 \\
\hline VI & 18.3 & 8.1 & 26.4 \\
\hline VII & 16.7 & 9.3 & 26.0 \\
\hline VIII & 8.7 & 19.6 & 28.3 \\
\hline $\begin{array}{c}\text { Chi-square } \\
p\end{array}$ & $\begin{array}{l}32.75 \\
<0.001\end{array}$ & $\begin{array}{r}18.89 \\
<0.01\end{array}$ & $\begin{array}{l}51.64 \\
<0.001\end{array}$ \\
\hline
\end{tabular}

\section{DISCUSSION}

The studies presented in the paper show that the world population of European bison is characterized by a high inbreeding coefficient, particularly in the United States and Canada. In the latter case this is undoubtedly due to the isolation of this subpopulation and consequently to frequent mating full sibs or sometimes to mating of even more closely related animals.

This high degree of inbreeding is not encountered among domestic cattle. Hodges (1978) estimated the value of the inbreeding coefficient in the herd of Holstein-Friesian cattle as within limits of $3 \%$ to $16 \%$, while Miksik and Kadecka (1979) estimated average inbreeding coefficient in a herd of lowland cattle as only $9.6 \%$.

The present studies show that the value of the inbreeding coefficient does not affect neither the age of first calving nor the number of calves produced by one female, but does affect the mean length of the period between calvings. In studies on domestic cattle it is possible to find partial confirmation of the results obtained here, for instance in a herd of Gir breed cattle inbreeding does not affect the age of first calving nor length of interval between calvings (Odedra et al., 1977). The unfavorable effect of inbreeding on length of interval between calvings was established by Hodges (1978). In the case of sheep inbreeding has an unfavorable effect on the number of lambs at one litter (Radomska \& Skoczylas, 1974).

A highly negative relation was found in European bison between value of the inbreeding coefficient and the animal's length of life. Inbreeding was found to be particularly harmful to the vitality of young animals, 
since increase in the percentage of deaths among young animals takes place with increased inbreeding. The hypothesis may therefore be put forward that a selective mechanism operates in such case, directed against animals with a high inbreeding coefficient, but only when inbreeding depression is evident in them, that is, negative characters conditioned by harmful recessive genes occur in them. This assumption finds indirect confirmation in the studies by Onopiuk (1984) made only on material from Białowieża. He found that highly inbred European bison which survived were characterized by better reproduction indices than animals less inbred but burdened with the negative result of inbreeding. Saltis (1960) makes a similar statement, considering that inbreeding may lead equally to deterioration or to improvement in the vitality of European bison.

The influence of such factors as place of birth, month or year of birth on life length and reproduction in European bison is of a sequent character and is primarily connected with the degree of the animals' inbreeding. European bison born in winter live for a shorter time and reproduce worse, probably because they are simultaneously more inbred and inbreeding has a harmful effect on the length of the period between calvings, while calvings are extended in time. The European bison born in USA and Canada, which are more inbred than other, reproduce worse and live a shorter time because they breed with very closely related mates.

Many authors consider that European bison do not exhibit any signs of degeneration and it is therefore to be concluded that natural selection directed against young animals with symptoms of inbreeding depression has proved of assistance in the restitution of this species.

Such indices, obtained from very abundant material, as mean length of life, age at first calving, mean interval between calvings and number of calves produced by one mother are similar to the corresponding indices estimated by Krasiński and Raczyński (1967).

\section{REFERENCES}

1. [EBPB, 1946-1978] Pedigree Book of the European bison, 1949-1965. Publ by the Intern. Soc. for the Protect. of the European bison. Ed. J. Zabiński. Polish Sci. Publ.: 1-370. Warszawa.

European bison Pedigree Book, 1965-1976. National Council for Nature Conservation. Eds J. Żabiński \& J. Raczyński (1965-1973), K. Krysiak \& Z. Woliński, (1974), W. Pilarski \& Z. Woliński (1975-1976). Polish Sci. Publ.: 1-352. Warszawa.

European Bison Pedigree Book, 1977-1978. National Council for Nature Conservation. Eds W. Pilarski \& Z. Woliński. State Publ. for Agric. and Forestry: 1-88. Warszawa. 
2. Dinkel C. A., 1972: Effects of inbreeding on fertility of beef cattle. J. Anim. Sci., 35: 725-729.

3. Hodges J., Tannen L., McGillivray B. J., Hiley P. G., \& Ellis S., 1979: Inbreeding levels and their effect on milk fat and calving interval in Holstein Friesian. Can. J. Anim. Sci., 59: 153-158.

4. Keller D. G. \& Brinks J. A., 1978: Inbreeding by environment interactions for weaning weight in Hereford cattle. J. Anim. Sci., 46: 48-54.

5. Krasiński Z. \& Raczyński J., 1967: The reproduction biology of European bison living in reserves and in freedom. Acta theriol., 12: 407-444.

6. Miksik J. \& Kadecka J., 1979: Mle ňna uzitkovost na 1 lactaci u inbrednych krav českeho strakateho skotu. Z̃ivocis Vyr., 74: 131-136.

7. Odedra B. A., Kaushik S. N. \& Katoatal B. G., 1977: A note on the studies on inbreeding effects on production and reproductive characters in Gir cattle. Ind. J. Anim. Sci., 47: 824-826.

8. Onopiuk W., 1984: Historia, warunki utrzymania i analiza wplywu inbredu na rozród i dlugość życia żubrów w Białowieży. Master Degree Theses, Warsaw Agric. Univ.: 1-96.

9. Radomska M. J., 1982: Metody i kierunki doskonalenia zwierząt. PWN: 1-247. Warszawa.

10. Radomska M. J., Burzyńska B. \& Fiszdon K., 1983: Wplyw inbredu na poziom niektórych cech koni arabskich. Koń Polski, 3: 8-9.

11. Radomska M. J. \& Skoczylas A., 1974: Wplyw inbredu na produkcyjność owiec Rocz. Nauk Roln., B 96, 2: 19-28.

12. Robertson A., 1954: Inbreeding and performance in British Friesian cattle. Proc. Brit. Soc. Anim. Prod.: 87-92.

13. Slatis M. A., 1960: An analysis of inbreeding in the European bison. Genetics, 45: 275-287.

14. Wright S., 1922: Coefficients of inbreeding and relationship. Amer. Nat., 56: $330-338$.

Received 11 February, Accepted 10 May 1987.

Wanda OLECH

\section{ANALIZA INBREDU ŻUBRÓW}

\section{Streszczenie}

W oparciu o Księgę Rodowodową Zubra prześledzono rodowody 3617 żubrów o znanym obustronnym pochodzeniu.

Dla każdego osobnika oszacowano wielkość wspólczynnika inbredu posługując się własnym programem opartym na wzorze Wrighta (1922). Obliczono też długość życia, a dla matek wiek pierwszego wycielenia, liczbę cieląt i średni odstęp między wycieleniami. Zwierzęta zostały podzielone ze względu na rok, miesiąc lub miejsce urodzenia. Wyróżniono następujące miejsca urodzenia: Europa bez Polski i ZSSR, ZSSR, USA i Kanada i Polska. Podstawą jeszcze jednej klasyfikacji materiału była wielkość współczynnika inbredu zwierząt; podzielono je na 8 grup inbredowych. Oszacowano współczynniki korelacji i regresji liniowej między współczynnikiem inbredu a pozostalymi cechami. Przy pomocy testu chi-kwadrat zbadano 
istnienie związku między wielkością inbredu a procentem upadków cieląt i młodzieży. Wyniki zawarte są w 7 tabelach i 4 rysunkach.

Odrodzona populacja żubra jest wysoko zinbredowana, średnia wartość współczynnika inbredu $F=0.210 \pm 0.002$, a kilkadziesiąt osobników ma wspólczynnik inbredu wyższy niż $50 \%$ (Ryc. 1 ).

W miarę wzrostu inbredu wydluża się średni okres między wycieleniami, natomiast inbred nie wpływa na wiek pierwszego wycielenia oraz liczbę cieląt od jednej matki (Tab. 6), co jest dobrą prognozą na dalszy rozwój hodowli.

Stwierdzono ujemną, istotną korelację między wielkością inbredu a długością życia żubrów (Tab. 6). Znaleziono także istotną wprost proporcjonalną zależność między stopniem zinbredowania a procentem upadków cieląt i młodzieży (Tab. 7).

Wydaje się, że żubry wysoko zinbredowane, u których ujawnila się depresja inbredowa są eliminowane $\mathrm{z}$ hodowli $\mathrm{w}$ młodym wieku. Tym samym naturalna selekcja nie dopuszcza do ujawnienia się ujemnych skutków inbredu. Wiąże się to, być może z sukcesem jakim jest restytucja tego gatunku. 